terpretation in a specific, though large, body of case-law. It thereby tries to make up for the deficiencies of previous methodological works, which were typically over-arching, focussing on what they identified as the 'most important' cases in the entire case-law. Those studies could therefore only reach very broad conclusions, such as that the Court relies on effet utile, uses the four or five traditional methods of interpretation, or applies other interpretive approaches such as lex specialis or e contrario arguments. In contrast, this book pinpoints certain interpretive formulas in the case-law, traces them through the entire story of the caselaw under scrutiny, and assesses their power. These interpretive formulas have so far not received sufficient attention.

\title{
VI An illustration of how this book is different from other works
}

As an illustration of the usefulness and novelty of this book, let us consider four examples of scholarship discussing broad and restrictive interpretation, an interpretation that is, among other interpretations, dealt with in the part of this book on 'the evolution of interpretive formulas'. A classic passage in Hans Kutscher's influential contribution of 1976 notes: The 'Community Treaties, as the constitution of the Community, are to be interpreted broadly rather than restrictively, according to the methods of interpretation applicable to constitutional jurisdiction, and thus like national constitutional law'15. It continues: 'The exception which the Treaty makes to the basic rules of equality of treatment, freedom of movement and freedom to provide services have been consistently given a narrow interpretation by the Court' (p. I-37), citing as examples Van Duyn, 1974, and Rutili, 1975. ${ }^{16}$ A passage from a book of 1978 by another prominent author, Anna Bredimas, reads: '[T]he Court has adopted the principle that exceptions to general Community rules and derogations to Treaty obligations must be restrictively interpreted. This is the case where a narrow construction has been applied in order to promote the purposes of the Treaty and reinforce Community efficacy. Its application is so consistent that the case law bristles with examples of it. ${ }^{17}$ This statement is supported with passages from seven judgments stemming from the whole spectrum of the Court's case-law. In 1993, a third leading author, Joxerramon Bengoetxea, in his book quotes the above passage

Gisbert Brinkmann (eds), Perspektivwechsel im Ausländerrecht (Baden-Baden: Nomos, 2007), pp. 49-60, in particular p. 60. On the way scholarship has changed: Anthony Arnull, 'The Americanization of EU Law Scholarship', in Anthony Arnull, Piet Eeckhout and Takis Tridimas (eds), Continuity and Change in EU Law (Oxford: OUP, 2006), pp. 415-431; and more broadly on judges: Daniel Thürer, 'Die Worte des Richters - Gedanken rund um die Verfassungsgerichtsbarkeit', in Stefan Hammer, Alexander Somek, Manfred Stelzer and Barbara Weichselbaum (eds), Demokratie und sozialer Rechtsstaat in Europa - Festschrift für Theo Öhlinger (Wien: WUV, 2004), pp. 272-297.

15 Kutscher, 'Methods of Interpretation as Seen by a Judge at the Court of Justice', p. I-31.

16 That Kutscher does not cite any services cases to support this statement is not surprising given that the three cases with a services dimension which had been decided up to that point - Sacchi, 1974; Van Binsbergen, 1974; and Coenen, 1975 - did not contain any evident passage to that effect.

17 Anna Bredimas, Methods of Interpretationsand Community Law p. 109-110-(footnote omitted). 
on the broad interpretation of the constitutional treaties by Kutscher and adds a 'corollary criterion, i. e. that exceptions to fundamental Community principles are to be narrowly interpreted (see, in general, jurisprudence on article 36) ${ }^{118}$. Later in his book he identifies 'the directive that „exceptions to fundamental rules (principles) found in the Treaties are to be interpreted strictly "' (p. 246) as a conceptual argument, a systemic criterion. Finally, in a most recent book of 2012, Gunnar Beck examines 'topoi' of interpretation and states as to the restrictive interpretation mentioned in the above passages: 'The principle of the restrictive interpretation of derogations, exceptions, exemptions and exclusions has been well established since the 1970s. ${ }^{19}$ He cites Commission $v$. France (maritime worker quota), 1974 as proof and goes on: '[...] [T] he distinction between a broad and a restrictive interpretation, the former designed to give maximum effect to general principles and fundamental rights and the latter ensuring that legitimate national policy prerogatives cannot be used to avoid treaty obligations, is somewhat artificial, not always easy to apply in practice, and in reality the judicial interpretation of a principle or right is determined by a congery of factors which include the area of law concerned as well 'extra-legal' motivational factors' (p. 204).

These are passages from four of the most authoritative works on the Court's methods of interpretation. The above statements are basically all these works say about the notion that some terms are subject to broad while others to restrictive interpretation (while they, of course, say much more than this book about other aspects of interpretation). These statements all suffer from three deficiencies which this book attempts to remedy. (i) They all rely on a selective, anecdoctal range of cases, namely one, two, seven or an undefined range of cases. In contrast, the evidence this book relies on is comprehensive. All occurrences of the idea, which is mentioned in the above statements, in the body of case-law identified in the first part are documented. The conclusions this book is able to draw are thus firm and reliable. The conclusions of this book rely on evidence, not eminence. (ii) The ambition of all of the above statements is strong. They all extrapolate and claim to apply to the entire case-law of the Court. In contrast, this book is more modest. It does not work with inference. Its conclusions only relate to a clearly identified body of case-law, the case-law on free movement of persons and services. (iii) The content of the above statements is weak. They only say that interpretation is consistently narrow, that a principle is consistently applied, that there is a directive to interpret exceptions strictly, or that this directive is somewhat artifical, not always easy to apply, and subject to influence by extra-legal factors (see the above statements). In contrast, this book attempts to come to firmer conclusions with regard to such 'directives'. Its thick description offers more context and allows the reader to identify the circumstances in which the 'directives' are deployed. This book is thus not satisfied with plain conclu-

18 Joxerramon Bengoetxea, The Legal Reasoning of the European Court of Justice, p. 233.

19 Beck, The Legal Reasoning of the Gourt of Justice of the EU, po. 204 (italics removed). 
sions such as that a specific interpretation is not easy to apply in practice and subject to extra-legal factors. Rather, it combines methods and substantive law to reach more solid conclusions.

What distinguishes this book most clearly from the above works, though, is an element that seems to be foreign to those works, partly because of the three points identified above, namely that the broad/restrictive interpretation they identify might constitute an interpretive formula, a formula that evolves over the years, one that exercises a certain function within decisions and exerts a certain power - spin' - that is of interest. It is in these regards that this book breaks fresh academic ground. This, in turn, again generates practical value. The book enables practitioners representing natural persons in the internal market to predict more accurately whether certain notions in persons and services will be interpreted broadly or restrictively by the courts, to name just one formula examined in this book. Thus, ideally, the book, owing to its depth, should allow lawyers to strengthen their cases and bind the Court to its own logic. Underlying the approach of this book is obviously the belief that it matters what the Court writes in its decisions. The idea that the grounds of a judgment constitute merely ex post justification for majoritarianism or for other unmentioned 'exogenous' factors is too simple. Moreover, a Court that speaks to several hundreds of millions of people does not mention passages, formulas, and even single words by accident. Formulas do not just slip in. We have to take every word the Court writes seriously.

\section{What this book is not}

Why is there so little discussion of academic writings in this book, in particular in the part on 'the case-law'? Why are there not more footnotes quoting scholarship to underpin a statement made in the text? The terseness in terms of footnotes and quoting is owed to the rigorously scientific approach applied in this book. ${ }^{20}$ The body investigated is not academia's publications, but a certain, clearly delineated body of case-law established by the Court of Justice - see the description above. This large body of case-law is the data the book uses and relies on. Consequently, this book can only make reliable statements with regard to this case-law, and not with regard to academic writings. A full investigation of academic writings - and in order to live up to scientific rigour it would necessarily have to be full - would be a different project, one that would for instance investigate the evolution of interpretive formulas or their reception in academic writing. Hence, this book uses academic writings for one purpose only, namely

20 Note also that in-text citations rather than footnotes are used for references to case-law. 